\title{
PENGARUH LAMA WAKTU FERMENTASI KOMBUCHA ROSELA (Hibiscus sabdariffa L.) TERHADAP AKTIVITAS ANTIBAKTERI Escherichia coli
}

\author{
Adinda Ismu Cholidah ${ }^{1}$, Dwi Danu ${ }^{2}$, Iif Hanifa Nurrosyidah ${ }^{3}$ \\ ${ }^{1,2}$ STIKES Rumah Sakit Anwar Medika \\ ${ }^{3}$ Departemen Biologi Farmasi, STIKES Rumah Sakit Anwar Medika \\ Email korespondensi: iifhanifanurrosyidah@gmail.com
}

\begin{abstract}
ABSTRAK
Bunga rosela (Hibiscus sabdarifa L.) merupakan salah satu tanaman obat keluarga yang sering digunakan sebagai obat tradisional. Bunga rosela (Hibiscus sabdarifa L.) mengandung senyawa fenolik seperti tanin, saponin dan flavonoid yang bersifat sebagai antibakteri. Bunga rosela (Hibiscus sabdarifa L.) memiliki potensi untuk dijadikan minuman teh kombucha. Kombucha bermanfaat sebagai antibakteri, antikanker, memperbaiki fungsi hati, antikolesterol, penangkal racun memperbaiki sistem pencernaan dan menjaga stamina tubuh. Tujuan penelitian ini yaitu untuk mengetahui pengaruh waktu fermentasi kombucha rosela (Hibiscus sabdarifa L.) terhadap aktivitas antibakteri Escherichia coli. Kombucha rosela dibuat dengan cara memfermentasikan rebusan bunga rosela, starter $10 \%$ dan gula 10\% selama 1 hari, 3 hari, 5 hari, 7 hari, 9 hari, 11 hari, 13 hari dan 15 hari. Selanjutnya dilakukan uji aktivitas antibakteri dengan metode Cup-plate technique. Hasil penelitian menunjukkan bahwa fermentasi kombucha rosela mampu menghambat pertumbuhan bakteri Escherichia coli dengan hasil yang berbeda sesuai dengan lama waktu fermentasi. Analisis data menggunakan uji Spearman menunjukkan hasil waktu fermentasi sangat berpengaruh terhadap aktivitas antibakteri Escherichia coli dan dilanjutkan uji Mann Whitney menunjukkan fermentasi kombucha rosela memiliki daya hambat yang signifikan terhadap pertumbuhan bakteri. Zona hambat paling optimum menghambat bakteri Escherichia coli adalah fermentasi kombucha rosela 15 hari sebesar 21,5 mm yang dikategorikan dengan daya aktivitas antibakteri sangat kuat.
\end{abstract}

Kata kunci : kombucha, antibakteri, bunga rosela (Hibiscus sabdariffa L) 


\title{
EFFECT OF FERMENTATION TIME KOMBUCHA ROSELA (Hibiscus sabdariffa L.) ON ANTIBACTERIAL ACTIVITY OF Escherichia coli
}

\begin{abstract}
Roselle flower (Hibiscus sabdarifa L.) is one of the medicinal plants which is often used as traditional medicine. Roselle flower (Hibiscus sabdarifa L.) contains phenolic compounds such as tannins, saponins and flavonoids that are as antibacterial. Roselle flower (Hibiscus sabdarifa L.) can be made as a kombucha tea. Kombucha ia useful as an antibacterial, anticancer, improves liver function, anticholesterol, detoxification, improves the digestive system and maintains stamina. The purpose of this research were to find out the effect of kombucha roselle (Hibiscus sabdarifa L.) fermentation time against antibacterial activity of Escherichia coli. Kombucha roselle made by fermenting roselle stew, starter 10\% and sugar 10\% for 1 day, 3 days, 5 days, 7 days, 9 days, 11 days, 13 days and 15 days. Then, testing the effectiveness of antibacterial by method Cup-plate technique. The results showed that fermentation of kombucha rosella was able to inhibit the growth of Escherichia coli bacteria with different results according to the length of fermentation time. The results of data analysis using spearman test showed the fermentation time were take effect on e.coli antibacterial activity and continued with Mann Whitney test showed the fermentation of kombucha roselle has a significant inhibitory effect on bacterial growth. The most optimum inhibitory zone in inhibiting Escherichia coli is 15 days fermentation of kombucha roselle for $21,5 \mathrm{~mm}$ wich is categorized as very strong antibacterial activity.
\end{abstract}

Keywords : kombucha, antibacterial, Roselle Flower (Hibiscus sabdariffa L.)

\section{PENDAHULUAN}

Penyakit infeksi merupakan suatu penyakit yang disebabkan karena adanya mikrooganisme meliputi bakteri, virus, jamur dan parasit (Kowalk dan Jeniffer, 2011). Salah satu penyakit infeksi yang umum terjadi yaitu infeksi saluran pencernaan seperti infeksi diare. Infeksi saluran pencernaan sendiri umum terjadi di seluruh dunia yang menyebabkan morbiditas dan mortalitas (Sukandar et al., 2008).

Kasus diare banyak terjadi di negara-negara berkembang dengan standar hidup yang rendah (Tjay dan

Rahardja, 2007). Penyakit diare merupakan penyakit endemis di indonesia dan juga merupakan penyakit potensial Kejadian Luar Biasa (KLB) yang disertai dengan kematian (Kemenkes RI, 2018). Hasil Riskesdas (2018) menyebutkan bahwa insiden diare di indonesia pada tahun 20132018 mengalami peningkatan. Prevalensi diare berdasarkan diagnosis tahun 2013 sebesar 4,5\% dan meningkat menjadi $6,8 \%$ pada tahun 2018, sedangkan berdasarkan diagnosis dan gejala penyakit tahun 2013 sebesar 7\% 
dan meningkat menjadi $8 \%$ pada tahun 2018. Diare pada balita berdasarkan diagnosis tahun 2013 sebesar 2,4\%, tahun 2018 sebesar 11\%. Insiden diare di provinsi Jawa Timur pada berdasarkan diagnosis dan gejala penyakit tahun 2013 sebesar 4,7\%, tahun 2018 sebesar 6,5\%, diare pada balita berdasarkan diagnosis dan gejala penyakit tahun 2013 sebesar $6,6 \%$ dan tahun 2018 sebesar 10,7\%.

Diare merupakan peningkatan volume feses dan frekuensi defekasi yang dipengaruhi oleh banyaknya kandungan air serta keberadaan makanan yang tidak dapat diserap oleh kolon (Kowalk dan Jeniffer, 2011). Diare akut infeksi diklasifikasikan menjadi diare non inflamasi dan diare inflamasi. Diare inflamasi disebabkan invasi bakteri dan sitotoksik di kolon yang ditandai dengan adanya lendir dan darah sehingga dapat menyebabkan abdomen terasa mulas sampai nyeri, mual, muntah, demam, dan dehidrasi. Pemeriksaan tinja ditemukan sel leukosit polimorfonuklear. Diare non inflamasi disebabkan oleh enterotoksin yang mengakibatkan diare cair tanpa disertai lendir dan darah. Pada pemeriksaan tidak ditemukan leukosit (Zein et al., 2004).

Bakteri patogen yang dapat menyebabkan infeksi diare yaitu Escherichia coli dan Staphylococcus aureus. Escherichia coli tergolong bakteri Gram negatif yang merupakan flora normal pada usus. Bakteri ini memiliki 2 jenis toksin (enterotoksin) yaitu yang termolabil (LT) dan termostabil (ST). Toksin LT (termolabil) dapat menyebabkan penderita mengalami diare, akibat cara kerjanya dapat merangsang enzim adenilat siklase pada mukosa usus halus. Toksin ST (termostabil) berperan dalam merangsang aktifnya enzim gunilat siklase yang berperan dalam pembentukan guanosin monofosfat siklik yang berakibat terjadinya gangguan klorida (Cl-) dan natrium $(\mathrm{Na}+)$ serta dapat menurunkan motilitas usus halus (Kurniawan dan Shali, 2017). Bakteri Escherichia coli dapat menyebabkan infeksi pada manusia seperti infeksi saluran kemih, meningitis pada neonatus dan infeksi diare (Radji, 2010; Kuswiyanto, 2016).

Pengobatan yang dilakukan pada pasien infeksi diare yaitu antibiotika. Antibiotika yang sering digunakan yaitu ampisilin, amoksisilin, kotrimoksazol, kloramfenikol dan tetrasiklin. Penggunaan antibiotik yang tidak rasional (tidak tepat indikasi, tidak tepat dosis, tidak tepat cara pemberian, penggunaan secara terusmenerus/jangka panjang) dapat menyebabkan resistensi bakteri terhadap antibiotik (Kemenkes, 2011; WHO, 2002). Berdasarkan uraian di atas terkait kekurangan dari penggunaan antibiotik, maka pengobatan infeksi dengan menggunakan bahan alam menjadi salah satu alternatif untuk mengatasi permasalahan tersebut.

Tumbuhan yang berkhasiat sebagai obat sudah dimanfaatkan oleh masyarakat sejak zaman dahulu. Pengobatan tradisional terhadap penyakit tersebut menggunakan bahan dasar dari tumbuhan dan segala sesuatu yang berada di alam. Sampai sekarang 
obat herbal banyak diminati oleh masyarakat karena bahan-bahannya dapat ditemukan dengan mudah di lingkungan sekitar (Mulyani et al,. 2016). Salah satu tanaman obat yang dapat digunakan sebagai antibakteri adalah rosela (Hibiscus sabdariffa L.).

Rosela (Hibiscus sabdariffa L.) merupakan salah satu tanaman yang memiliki aktivitas antimikroba, antioksidan, anti-inflamasi, antidiabetes, antihipertensi dan antifungial (Nurnasari dan Khuluq, 2017). Antimikroba pada rebusan bunga rosela ditunjukkan oleh senyawa polifenol seperti flavonoid yaitu antosianin dan gosypetin, fenolik, tannin dan saponin dengan konsentrasi 10\% - 70\% tidak menghambat bakteri Escherichia coli dan konsentrasi 80\% - 100\% dapat menghambat pertumbuhan bakteri Escherichia coli (Estri dan Anggarbeni, 2015). Penelitian yang dilakukan sebelumnya oleh Jung et al., (2013) menunjukkan bahwa kandungan polifenol pada ekstrak bunga rosela dapat menghambat pertumbuhan bakteri Bacillus subtilis, Escherichia coli dan Staphylococcus aureus.

Salah satu pengolahan rosela adalah dapat dijadikan minuman kombucha rosela. Teh kombucha sendiri merupakan minuman hasil fermentasi larutan teh manis dengan memanfaatkan pertumbuhan simbiosis antara yeast (Saccharomyces cerevisiae, Saccharomyces ludwigii, Saccharomyces apiculatus varictas, Saccharomycespombe) dan bakteri (Acetobacter xylinum, gluconicum, Acetobacter ketogenum Pichia fermentas, Torula varietas), fermentasi dapat dilakukan selama 7-14 hari. Kombucha banyak dikonsumsi masyarakat sebagai minuman kesehatan karena memiliki banyak senyawa yang berkhasiat yaitu berbagai macam vitamin (B1, B2, B3, B6, B12, B15 dan C), polifenol yang memiliki efek antioksidan, dapat mempengaruhi tubuh secara menyeluruh dengan menstabilkan metabolisme tubuh, penawar racun dan berbagai jenis asam (asam asetat, asam glukoronat, asam laktat, asam karbonat, asam folat, asam glukonat, asam condroitin sulfat dan asam hyaluronic) (Naland, 2008). Asam asetat berperan sebagai antibakteri dengan cara mendenaturasi protein yang dapat menyebabkan aktivitas metabolisme sel bakteri berhenti (Simanjuntak dan Kurniawaty, 2019).

Penelitian sebelumnya yang dilakukan oleh Deghrigue et al. (2013) menunjukkan bahwa kombucha teh hitam dan teh hijau mampu menghambat pertumbuhan bakteri Escherichia coli, Pseudomonas aeruginosa, Staphylococcus epidermidis dan Staphylococcus aureus. Dalam pembuatan kombucha dapat menggunakan tanaman selain teh hitam dan teh hijau salah satunya yaitu rosela. Pada penelitian yang dilakukan Suhartatik et al. (2009) kombucha rosela dapat digunakan sebagai antikolestrolemia, sedangkan banyaknya kandungan senyawa fitokimia yang berperan sebagai antibakteri membuat bunga rosela sangat berpotensi untuk dijadikan sebagai minuman kombucha rosela. Oleh karena itu pada penelitian ini akan 
dilakukan uji aktivitas kombucha rosela terhadap bakteri Escherichia coli menggunakan metode uji difusi sumuran dengan konsentrasi $100 \%$ dan fermentasi selama $1,3,5,7,9,11,13$ dan 15 hari.

\section{METODE PENELITIAN}

\section{Material}

Alat yang digunakan dalam percobaan ini yaitu timbangan digital, pinset, gelas ukur, erlenmeyer, beaker gelas, gunting, batang pengaduk, corong gelas, tabung reaksi dan raknya, gelas arloji, penangas air, dan oven. Alat untuk uji aktivitas antibakteri meliputi cawan Petri (PetriQ), plastik wrap, bunsen burner, jarum ose, mikropipet, sterilizing cupboard (Elitech/ZTP8O ECOh), shaker rotation (Health/H-

\section{Pembuatan Kombucha Rosella}

Pembuatan kombucha rosela dilakukan dengan cara menimbang simplisia bunga rosela sebanyak 250 gram, selanjutnya masukkan dalam 500 $\mathrm{ml}$ air kemudian direbus sampai volume tersisa $250 \mathrm{ml}$ dan disaring dengan kain kasa steril, maka diperoleh konsentrasi $100 \%$. Kemudian tambahkan gula $10 \%$ dari volume total dan disterilkan selama
MSR), inkubator (memmert), LAF (Lamnar Air Flow) (WINA:304) dan autoklaf (GEA/IS-B75L).

Bahan utama yang digunakan dalam percobaan ini yaitu starter kombucha. Starter kombucha diperoleh dari WikiKombucha di Bali. Simplisia rosela diperoleh dari UPT Materia Medica Batu dan gula pasir. Skrining fitokimia menggunakan bahan, reagen Wagner, Mayer, Dragebdorf, LibermanBuchard, $\mathrm{FeCl}_{3} 1 \%$, HCL $2 \mathrm{~N}$ dan serbuk Mg. Uji aktivitas antibakteri menggunakan media Nutrien Agar (NA), BaCl, media Muller Hinton Agar (MHA), Akuades steril, biakan bakteri Escherichia coli dan Staphylococcus aureus.

\section{Rancangan Penelitian}

15 menit, tunggu larutan hingga dingin (suhu dibawah $50{ }^{0} \mathrm{C}$ ), ditambahkan $10 \%$ starter dari volume total. Setelah itu, erlenmeyer ditutup rapat dan dibungkus dengan kasa. Difermentasi selama $1,3,5,7,9,11,13,15$ hari dalam kondisi gelap dan pada suhu ruang. Formulasi kombucha rosela dapat dilihat secara detail pada tabel 1 dibawah ini.

Tabel 1 Formulasi Kombucha Rosela

\begin{tabular}{|c|c|c|c|c|c|c|c|c|c|}
\hline \multirow[t]{2}{*}{ Bahan } & \multicolumn{8}{|c|}{ Lama Fermentasi (Hari) } & \multirow[t]{2}{*}{ Fungsi } \\
\hline & F1 & F3 & F5 & F7 & F9 & F11 & F13 & F15 & \\
\hline Simplisia & 100 & 100 & 100 & 100 & 100 & 100 & 100 & $100 \%$ & Bahan Aktif \\
\hline Rosela & $\%$ & $\%$ & $\%$ & $\%$ & $\%$ & $\%$ & $\%$ & & \\
\hline Starter & 10 & 10 & 10 & 10 & 10 & $10 \%$ & $10 \%$ & $10 \%$ & Agen \\
\hline (SCOBY) & $\%$ & $\%$ & $\%$ & $\%$ & $\%$ & & & & Fermentasi \\
\hline Gula & $\begin{array}{l}10 \\
\%\end{array}$ & $\begin{array}{l}10 \\
\%\end{array}$ & $\begin{array}{l}10 \\
\%\end{array}$ & $\begin{array}{l}10 \\
\%\end{array}$ & $\begin{array}{l}10 \\
\%\end{array}$ & $10 \%$ & $10 \%$ & $10 \%$ & $\begin{array}{c}\text { Makanan } \\
\text { koloni } \\
\text { bakteri-jamur }\end{array}$ \\
\hline
\end{tabular}




$\begin{array}{cccccccccc}\text { Akuades } & \mathrm{Ad} & \mathrm{Ad} & \mathrm{Ad} & \mathrm{Ad} & \mathrm{Ad} & \mathrm{Ad} & \mathrm{Ad} & \mathrm{Ad} & \text { (SCOBY) } \\ & 500 & 500 & 500 & 500 & 500 & 500 & 500 & 500 \mathrm{ml} & \\ & \mathrm{ml} & \mathrm{ml} & \mathrm{ml} & \mathrm{ml} & \mathrm{ml} & \mathrm{ml} & \mathrm{ml} & & \end{array}$

\section{Skrining Fitokimia Kombucha Rosela}

Skrining fitokimia yang dilakukan yaitu saponin, flavonoid, alkaloid, tanin, polifenol, steroid dan terpenoid. Senyawa tersebut dilakukan untuk memastikan adanya senyawa yang bertanggung jawab sebagai antibakteri.

\section{Uji Saponin}

Uji Saponin dilakukan dengan cara sampel dimasukkan ke dalam tabung reaksi, kemudian ditambahkan HCL $2 \mathrm{~N}$ sebanyak $5 \mathrm{ml}$, kemudian larutan didinginkan dan kocok selama 30 detik. Apabila terbentuk busa yang tidak hilang selama 30 detik menunjukkan adanya saponin (Sari \& Aryantini, 2018).

\section{Uji Flavonoid}

Uji Flavonoid dilakukan dengan cara sampel diuapkan hingga kering, ditambahkan 2-3 tetes etanol kemudian ditambahkan serbuk $\mathrm{Mg}$ dan beberapa $\mathrm{HCl}$ 5M. Bila timbul warna merah hingga merah lembayung maka ekstrak mengandung flavonoid (Hanani, 2015).

\section{Uji Alkaloid}

Uji alkaloid dilakukan dengan cara sampel ditambahkan HCL $2 \mathrm{~N}$ sebanyak $5 \mathrm{ml}$, kemudian dilakukan uji dengan reagen Mayer, Wagner, dan Dragendorff. Hasil positif alkaloid ditunjukkan adanya endapan putih untuk peeaksi Mayer, warna coklat muda untuk pereaksi Wagner dan warna merah jingga untuk pereaksi Dragendorff (Sari \& Aryantini, 2018).

\section{Uji Tanin dan Polifenol}

Sampel diambil sebanyak $3 \mathrm{~mL}$, kemudian diekstraksi dengan Akuades panas dan didinginkan suhu ruang. Setelah itu ditambah 5 tetes $\mathrm{NaCl} 10 \%$ dan disaring. Filtrat dibagi menjadi 3 bagian A, B, dan C. Filtrat A sebagai blanko, filtrat B ditambahkan 3 tetes $\mathrm{FeCl}_{3} 1 \%$ dan filtrat $\mathrm{C}$ ditambah gelatin $10 \%$. Setelah itu diamati perubahan yang terjadi. Hasil positif ditunjukkan dengan terbentuknya warna hitam kebiruan atau hijau untuk larutan yang ditambahkan $\mathrm{FeCl}_{3}$ 1\% (polifenol) dan endapan putih untuk larutan yang ditambahkan gelatin $10 \%$ (tanin) (Hanani, 2015).

\section{Uji Steroid dan Terpenoid}

Fraksi non polar pada sampel diambil sebanyak 5 tetes, kemudian ditambahkan 1 tetes $\mathrm{H}_{2} \mathrm{SO}_{4}$ pekat dan 1 tetes asam asetat pekat. Perubahan warna menjadi merah/ungu menunjukkan positif adanya senyawa tripterpenoid. Sedangkan perubahan warna hijau menunjukkan positif adanya senyawa steroid (Hamad et al, 2017).

\section{Uji Organoleptik Kombucha Rosela}

Uji organoleptik dilakukan secara visual dengan melihat bentuk, warna, merasakan bau dan rasa (Sari dan Aryantini, 2018).

\section{Pengukuran pH Kombucha Rosela}

Diambil masing-masing $25 \mathrm{ml}$ larutan kombucha, kemudian diukur $\mathrm{pH}$ 
nya dengan menggunakan $\mathrm{pH}$ meter (Sari dan Aryantini, 2018).

\section{Uji Total Asam Kombucha Rosela Selama Waktu Fermentasi}

Uji total asam dilakukan dengan metode titrasi alkaimetri yaitu menentukan konsentrasi $\mathrm{NaOH}$ dengan cara melakukan standarisasi terhadap larutan $\mathrm{NaOH}$ menggunakan asam asetat kemudian menentukan persen total asam titrasi dengan cara mengambil sebanyak $25 \mathrm{ml}$ sampel ditambahkan dengan 3 tetes indikator fenolftalein, kemudian dititrasi dengan larutan $\mathrm{NaOH} 0,1 \mathrm{~N}$ sampai larutan berubah warna merah muda. Rumus yang digunakan untuk menentukan konsentrasi $\mathrm{NaOH}$ sebagai berikut:

$$
\mathrm{V}_{\mathrm{NaOH}} \times \mathrm{N}_{\mathrm{NaOH}}=\mathrm{V}_{\mathrm{CH} 3 \mathrm{COOH}} \mathrm{XN}_{\mathrm{CH} 3 \mathrm{COOH}}
$$

Keterangan:

$\begin{array}{ll}\mathrm{V}_{\mathrm{NaOH}} & : \text { Volume } \mathrm{NaOH}(\mathrm{mL}) \\ \mathrm{N}_{\mathrm{NaOH}} & : \text { Konsentrasi } \mathrm{NaOH}(\mathrm{N}) \\ \mathrm{V}_{\mathrm{CH} 3 \mathrm{COOH}} & : \text { Volume } \mathrm{CH} 3 \mathrm{COOH}(\mathrm{mL}) \\ \mathrm{N}_{\mathrm{CH} 3 \mathrm{COOH}} & : \text { Konsentrasi CH3COOH }(\mathrm{N})\end{array}$

Rumus yang digunakan untuk menentukan persen total asam titrasi sebagai berikut (Aridona et al. 2015):

$$
\% \text { TAT }=\frac{\mathrm{ml} \mathrm{NaOH}(\text { titran }) \times \mathrm{N}_{\mathrm{NaOH}} \times \mathrm{Fp} \times \mathrm{BM} \mathrm{CH} 3 \mathrm{COOH}}{\text { Sampel }(\mathrm{mg})} \times 100 \%
$$

Keterangan:

$\begin{array}{ll}\mathrm{N}_{\mathrm{NaOH}} & : \text { Konsentrasi } \mathrm{NaOH}(\mathrm{N}) \\ \mathrm{ml} \mathrm{NaOH} & : \text { Volume hasil titrasi } \\ \text { Sampel }(\mathrm{mg}) & : \text { Berat sampel } \\ \mathrm{Fp} & : \text { Faktor pengenceran } \\ \mathrm{BM}_{\mathrm{CH} 3 \mathrm{COOH}} & : 60,05\end{array}$

Metode Uji Aktivitas Antibakteri

\section{Rebusan Rosela}

Penelitian ini dilakukan dengan metode Cup-plate technique (difusi sumuran) dengan cara media dituangkan kedalam cawan Petri, kurang lebih sebanyak $15 \mathrm{ml}$, media dibiarkan dingin dan membeku lalu dibuat sumur pada media agar yang telah ditanami dengan bakteri dan pada sumur tersebut diberi agen antimikroba yang akan diuji kemudian diinkubasi pada waktu tertentu (18-24 jam) dan suhu tertentu $\left(37^{\circ} \mathrm{C}\right)$. Hasil pengamatan yang diperoleh berupa ada atau tidaknya daerah jernih yang terbentuk disekeliling sumuran yang menunjukkan zona hambat pada pertumbuhan bakteri (Pratiwi, 2008). 
Metode Uji Aktivitas Antibakteri

\section{Kombucha Rosela}

Penelitian ini dilakukan dengan metode Cup-plate technique (difusi sumuran) dengan cara media dituangkan kedalam cawan Petri, kurang lebih sebanyak $15 \mathrm{ml}$, media dibiarkan dingin dan membeku lalu dibuat sumur pada media agar yang telah ditanami dengan bakteri dan pada sumur tersebut diberi agen antimikroba yang akan diuji kemudian diinkubasi pada waktu tertentu (18-24 jam) dan suhu tertentu $\left(37^{\circ} \mathrm{C}\right)$. Hasil pengamatan yang diperoleh berupa ada atau tidaknya daerah jernih yang terbentuk disekeliling sumuran yang menunjukkan zona hambat pada pertumbuhan bakteri (Pratiwi, 2008)

\section{Uji Aktivitas Antibakteri Rebusan} Rosela dan Kombucha Rosela

\section{Pembiakan Bakteri Escherichia coli}

Pembuatan media Nutient Agar (NA) untuk peremajaan bakteri dilakukan dengan cara sebanyak 0,4 g media Nutrient Agar (NA) dilarutkan dalam air suling steril kemudian volumenya dicukupkan hingga $20 \mathrm{ml}$ dengan bantuan pemanasan sampai semua bahan terlarut. Disterilkan dalam autoklaf pada temperatur $121^{\circ} \mathrm{C}$ selama 15 menit.

Proses peremajaan bakteri Escherichia coli dilakukan dengan cara dimasukkan sebanyak $5 \mathrm{ml}$ media Nutrien Agar steril kedalam tabung reaksi steril, didiamkan pada temperatur kamar sampai sediaan memadat pada posisi miring kira kira kemiringan $45^{\circ}$. Diamkan selama 30 menit hingga media memadat. Setelah media Nutrien Agar memadat bakteri uji diremajakan dengan cara di swab menggunakan jarum ose secara steril pada Lemari Laminar Air Flow (LAF). Setelah itu biakan bakteri uji (Escherichia coli dan Staphylococcus aureus) di inokulasi dalam suhu $36^{\circ} \mathrm{C}$ selama 24 jam.

\section{Pembuatan Isolat Uji Escherichia coli}

a. Pembuatan Media Nutrient Broth (NB)

Pembuatan media Nutrient Broth (NB) untuk isolat uji dilakukan dengan cara ditimbang media Nutrient Broth (NB) sebanyak 0,64 g, lalu dilarutkan dalam air suling steril sedikit demi sedikit, kemudian dicukupkan volumenya hingga $60 \mathrm{~mL}$ dengan bantuan pemanasan sampai semua terlarut sempurna kemudian dibagi menjadi 6 tabung dan disterilkan dalam autoklaf pada temperatur $121^{\circ} \mathrm{C}$ selama 15 menit.

\section{b. Pembuatan Suspensi Bakteri}

Bakteri uji yang telah diinokulasi diambil 1 ose bakteri kemudian dimasukkan kedalam tabung yang berisi $10 \mathrm{ml}$ larutan Nutrient Broth (NB) dishaker selama 24 jam. Kemudian dilakukan penenceran $10^{-1}$, $10^{-2}, 10^{-3}, 10^{-4}$ dengan cara mengambil 1 $\mathrm{ml}$ suspensi bakteri dimasukkan kedalam $9 \mathrm{ml}$ akuades steril, didapatkan pengenceran $10^{-1}$. Kemudian diambil $0,1 \mathrm{ml}$ dari konsentrasi $10^{-1}$ dilarutkan dalam 9,9 ml akuades steril, didapatkan pengenceran $10^{-2}$. Kemudian diambil $0,1 \mathrm{ml}$ dari konsentrasi $10^{-2}$ dilarutkan dalam 9,9 ml akuades steril, didapatkan pengenceran $10^{-3}$. Kemudian diambil 
$0,1 \mathrm{ml}$ dari konsentrasi $10^{-3}$ dilarutkan dalam 9,9 $\mathrm{ml}$ akuades steril, didapatkan pengenceran $10^{-4}$ dari konsentrasi $10^{-4}$ digunakan untuk bakteri uji.

\section{Uji Antibakteri Terhadap Bakteri Escherichia coli}

Uji aktivitas antibakteri

dilakukan dengan cara media padat Muller Hinton Agar (MHA) diambil sebanyak 28,50 g dilarutkan dengan menggunakan akuades steril $750 \mathrm{ml}$, kemudian diamkan diatas kompor listrik hingga larut dan jernih, kemudian disterilkan dengan menggunakan autoklaf pada suhu $121^{\circ} \mathrm{C}$ selama 15 menit.

Muller Hinton Agar (MHA)
yang telah cair (suhu $40 \quad{ }^{\circ} \mathrm{C}$ )
dimasukkan kedalam 10 cawan Petri, ditambahkan suspensi bakteri uji dan ratakan hingga homogen, kemudian diamkan sampai membeku, pada setiap cawan Petri media agar dibagi dalam 34 wilayah untuk masing-masing replikasi (3 kali replikasi) dan kontrol negatif (Akuades) dengan cara memberi tanda pada bagian bawah cawan Petri. Kemudian dibuat lubang sumuran pada media yang telah padat sebanyak 3-4 sumur, dimasukkan larutan kombucha atau rebusan rosela dengan mikropipet sebanyak $50 \mu$ l. Setelah itu inkubasi cawan Petri pada suhu $36^{\circ} \mathrm{C}$ selama 24jam. Zona hambat diukur disekitar sumuran untuk tiap replikasi dan kontrol setelah diinkubasi selama 24 jam.

\section{Analisis Data}

Analisis data yang digunakan untuk uji aktivitas antibakteri kombucha rosela yang digunakan pada penelitian ini adalah analisis statistik parametrik dengan distribusi yang normal yaitu one way ANOVA untuk mengetahui perbedaan yang signifikan pada setiap setiap formula dan untuk mengetahui ada atau tidaknya perbedaan hubungan aktivitas antibakteri terhadap lama waktu fermentasi menggunakan uji LSD (Uji Lanjut BNT). Sedangkan untuk data yang tidak terdistribusi secara normal menggunakan analisis statistik non parametrik Kruskal Wallis untuk mengetahui perbedaan signifikan setiap formula dan Mann Whitney untuk mengetahui ada atau tidaknya perbedaan hubungan aktivitas antibakteri terhadap lama waktu fermentasi setiap kelompok. 


\section{HASIL DAN PEMBAHASAN}

\section{Hasil Skrining Fitokimia Rebusan \\ Rosela dan Kombucha Rosella}

Tabel 2 Hasil Skrining Fitokimia Rebusan Rosela dan Kombucha Rosela

\begin{tabular}{|c|c|c|c|c|c|c|c|}
\hline No & $\begin{array}{l}\text { Identifikasi } \\
\text { Metabolit } \\
\text { Sekunder }\end{array}$ & $\begin{array}{c}\text { Nama Uji } \\
\text { (Reagen) }\end{array}$ & $\begin{array}{c}\text { Hasil } \\
\text { Menurut } \\
\text { Literatur }\end{array}$ & $\begin{array}{c}\text { Hasil } \\
\text { Pngamata } \\
\text { n }\end{array}$ & 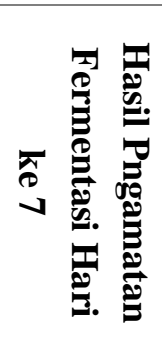 & 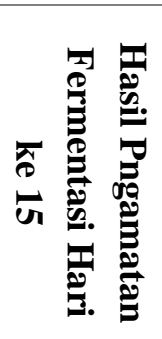 & $\begin{array}{l}7 \\
0 \\
0 \\
0 \\
0 \\
0 \\
0 \\
0 \\
0 \\
0 \\
0 \\
0\end{array}$ \\
\hline 1. & Saponin & $\begin{array}{l}+20 \mathrm{ml} \\
\text { akuads }\end{array}$ & $\begin{array}{l}\text { Terbentuk } \\
\text { busa }\end{array}$ & $\begin{array}{l}\text { Terbentuk } \\
\text { busa }\end{array}$ & + & + & + \\
\hline \multirow[t]{2}{*}{2.} & Flavonoid & $\begin{array}{l}2-3 \text { tetes } \\
\text { etanol }+ \\
\mathrm{HCL}+\end{array}$ & $\begin{array}{l}\text { Terbentuk } \\
\text { warna } \\
\text { merah }\end{array}$ & $\begin{array}{l}\text { Terbentuk } \\
\text { warna } \\
\text { merah }\end{array}$ & & & \\
\hline & & $\operatorname{logam} \mathrm{Mg}$ & $\begin{array}{l}\text { hingga } \\
\text { merah } \\
\text { lembayun } \\
\text { g }\end{array}$ & lembayung & + & + & + \\
\hline \multirow[t]{3}{*}{3.} & Alkaloid & $\begin{array}{l}+\mathrm{HCL} \\
2 \mathrm{~N} 5 \mathrm{ml} . \\
\mathrm{A}=\text { reagen } \\
\text { mayer }\end{array}$ & $\begin{array}{l}\mathrm{A}= \\
\text { reagen } \\
\text { mayer } \\
\text { (endapan } \\
\text { putih) }\end{array}$ & $\begin{array}{l}\mathrm{A}=\text { reagen } \\
\text { mayer } \\
\text { (endapan } \\
\text { putih) }\end{array}$ & + & + & + \\
\hline & & $\begin{array}{l}\mathrm{B}=\text { reagen } \\
\text { wagner }\end{array}$ & $\begin{array}{l}\mathrm{B}=\text { reagen } \\
\text { wagner } \\
\text { (coklat } \\
\text { muda) }\end{array}$ & $\begin{array}{l}\mathrm{B}=\text { reagen } \\
\text { wagner } \\
\text { (coklat } \\
\text { muda) }\end{array}$ & + & + & + \\
\hline & & $\begin{array}{l}\mathrm{C}=\text { reagen } \\
\text { dragendor } \\
\text { ff }\end{array}$ & $\begin{array}{l}\mathrm{C}=\text { reagen } \\
\text { dragendor } \\
\text { ff (merah } \\
\text { jingga) }\end{array}$ & $\begin{array}{l}\mathrm{C}=\text { reagen } \\
\text { dragendorff } \\
\text { (merah } \\
\text { jingga) }\end{array}$ & + & + & + \\
\hline \multirow[t]{2}{*}{4.} & $\begin{array}{l}\text { Polifenol dan } \\
\text { Tanin }\end{array}$ & $\begin{array}{l}\text { +akuads } \\
\text { panas, }\end{array}$ & $\begin{array}{l}\text { Filtrat A: } \\
\text { (hitam }\end{array}$ & $\begin{array}{l}\text { Filtrat A: } \\
\text { coklat }\end{array}$ & & & \\
\hline & & $\begin{array}{l}+\mathrm{NaCl} \\
10 \% \\
\text { Filtrat A: } \\
+3 \text { tetes } \\
\mathrm{FeCl}_{3}\end{array}$ & $\begin{array}{l}\text { kebiruan) } \\
+ \\
\text { polifenol }\end{array}$ & kemerahan & - & - & - \\
\hline
\end{tabular}




\begin{tabular}{|c|c|}
\hline $\begin{array}{l}\text { Filtrat B: } \\
\text { +garam } \\
\text { gelatin } \\
\text { (endapan } \\
\text { putih) + } \\
\text { tanin } \\
\text { Warna } \\
\text { merah/un } \\
\text { gu + } \\
\text { triterpenoi } \\
\text { d } \\
\text { Warna } \\
\text { hijau + } \\
\text { steroid }\end{array}$ & $\begin{array}{l}\text { Filtrat B: } \\
\text { merah ada } \\
\text { endapan } \\
\text { putih }\end{array}$ \\
\hline $\begin{array}{l}\text { Hasil identifikasi } \text { senyawa } \\
\text { saponin positif terlihat pada rebusan } \\
\text { bunga rosela dan kombucha rosela } \\
\text { fermentasi hari ke } 7 \text { dan ke } 15 \text { sebelum } \\
\text { penambahan akuades sampel tidak ada } \\
\text { busa dan setelah penambahan akuades, } \\
\text { dikocok selama } 30 \text { detik timbul busa } \\
\text { yang tidak hilang (stabil). Senyawa } \\
\text { flavonoid menunjukkan hasil positif } \\
\text { pada rebusan bunga rosela dan } \\
\text { kombucha rosela fermentasi hari ke } 7 \\
\text { dan ke } 15 \text { di mana terjadi perubahan } \\
\text { sebelum penambahan reagen sampel } \\
\text { berwarna merah tua dan setelah } \\
\text { penambahan reagen warna yang } \\
\text { terbentuk merah lembayung. Senyawa } \\
\text { alkaloid menunjukkan hasil positif pada } \\
\text { rebusan bunga rosela dan kombucha } \\
\text { rosela fermentasi hari ke } 7 \text { dan ke } 15 \text { di } \\
\text { mana terjadi perubahan warna sebelum } \\
\text { penambahan reagen sampel berwarna } \\
\text { merah tua dan terjadi perubahan setelah }\end{array}$ & $\begin{array}{l}\text { berwarna merah jingga. Senyawa } \\
\text { polifenol menunjukkan hasil negatif } \\
\text { teridentifikasi setelah penambahan } \\
\mathrm{FeCl}_{3} \text { sampel tidak berubah warna, } \\
\text { senyawa tanin menunjukkan hasil } \\
\text { positif teridentifikasi setelah } \\
\text { penambahan garam gelatin pada sampel } \\
\text { terbentuk endapan putih. Senyawa } \\
\text { Terpenoid menunjukkan hasil positif } \\
\text { teridentifikasi sebelum penambahan } \\
\text { reagen sampel berwarna merah tua } \\
\text { setelah penambahan reagen sampel } \\
\text { berubah warna merah. Hasil skrining } \\
\text { fitokimia yang diperoleh pada rebusan } \\
\text { bunga rosela dan kombucha rosela tidak } \\
\text { ada perbedaan senyawa yang } \\
\text { terkandung. Hasil skrining yang } \\
\text { diperoleh sesuai dengan literatur yang } \\
\text { ada di mana bunga rosela mengandung } \\
\text { senyawa saponin, flavonoid, alkaloid, } \\
\text { tanin dan triterpenoid (Estri dan } \\
\text { Anggarbeni, 2015; Mardiah et al. } \\
\text { 2015). }\end{array}$ \\
\hline
\end{tabular}

penambahan reagen mayer terdapat endapan putih, reagen wagner berwarna cokelat muda dan reagen dragendorff 
Tabel 3 Hasil Uji Organoleptik Rebusan Rosela dan Kombucha Rosela

\begin{tabular}{|c|c|c|c|}
\hline \multirow[t]{2}{*}{ Perlakuan } & \multicolumn{3}{|c|}{ Hasil Pengamatan } \\
\hline & Warna & Aroma & Rasa \\
\hline Rebusan Rosela & Merah tua pekat & Khas rosela & Manis \\
\hline $\begin{array}{l}\text { Fermentasi Kombucha } \\
\text { Hari ke } 1\end{array}$ & Merah tua pekat & $\begin{array}{l}\text { Khas rosela dan berbau } \\
\text { sedikit asam }\end{array}$ & Manis asam \\
\hline $\begin{array}{l}\text { Fermentasi Kombucha } \\
\text { Hari ke } 3\end{array}$ & Merah tua pekat & $\begin{array}{l}\text { Khas rosela dan berbau } \\
\text { asam }\end{array}$ & Manis asam \\
\hline $\begin{array}{l}\text { Fermentasi Kombucha } \\
\text { Hari ke } 5\end{array}$ & Merah tua pekat & $\begin{array}{l}\text { Khas rosela dan berbau } \\
\text { asam }\end{array}$ & Manis asam \\
\hline $\begin{array}{l}\text { Fermentasi Kombucha } \\
\text { Hari ke } 7\end{array}$ & Merah tua pekat & $\begin{array}{l}\text { Khas rosela dan berbau } \\
\text { asam }\end{array}$ & Manis asam \\
\hline $\begin{array}{l}\text { Fermentasi Kombucha } \\
\text { Hari ke } 9\end{array}$ & Merah tua pekat & $\begin{array}{l}\text { Khas rosela dan berbau } \\
\text { asam }\end{array}$ & Manis asam \\
\hline $\begin{array}{l}\text { Fermentasi Kombucha } \\
\text { Hari ke } 11\end{array}$ & Merah tua pekat & $\begin{array}{l}\text { Khas rosela dan berbau } \\
\text { asam }\end{array}$ & Manis asam \\
\hline $\begin{array}{l}\text { Fermentasi Kombucha } \\
\text { Hari ke } 13\end{array}$ & Merah tua & $\begin{array}{l}\text { Khas rosela dan berbau } \\
\text { asam }\end{array}$ & Manis asam \\
\hline $\begin{array}{l}\text { Fermentasi Kombucha } \\
\text { Hari ke } 15\end{array}$ & Merah tua & $\begin{array}{l}\text { Khas rosela dan berbau } \\
\text { asam }\end{array}$ & Manis asam \\
\hline
\end{tabular}

Hasil penelitian uji organoleptik kombucha rosela menunjukkan adanya perubahan rasa terhadap waktu fermentasi. Pada awal fermentasi kombucha rosela masih terasa manis, kemudian rasa asam muncul pada fermentasi hari selanjutnya. Semakin lama waktu fermentasi menyebabkan meningkatnya rasa asam pada kombucha. Hal ini dikarenakan khamir dan bakteri melakukan metabolisme terhadap sukrosa dan menghasilkan sejumlah asam-asam organik seperti asam asetat, asam glukonat dan asam glukoronat, sehingga rasa khas bunga rosela mulai menghilang dan digantikan oleh rasa asam (Wistiana dan Zubaidah. 2015).

Hasil penelitian uji organoleptik kombucha rosela menunjukkan adanya perubahan Aroma terhadap waktu fermentasi. Aroma asam pada kombucha rosela disebabkan oleh senyawa-senyawa volatile yang terbentuk sehingga menimbulkan aroma asam yang khas dan adanya komponen asam yang terbentuk saat proses fermentasi (Wistiana dan Zubaidah. 2015). Khamir dan bakteri melakukan metabolisme terhadap sukrosa dan menghasilkan sejumlah asam-asam organik seperti asam asetat, asam glukonat dan asam glukoronat (Wistiana dan Zubaidah. 2015). Menurut Simanjuntak et al (2016) semakin lama proses fermentasi, maka terjadi peningkatan senyawa kimia seperti asam asetat yang bersifat volatil yang akan menghasilkan aroma asam yang kuat dan khas.

Hasil penelitian uji organoleptik kombucha rosela menunjukkan adanya 
perubahan warna terhadap waktu fermentasi. Pada fermentasi hari ke 1, 3, 5, 7, 9 dan 11 kombucha rosela berwarna merah tua pekat, pada fermentasi hari ke 13 dan 15 warna kombucha rosela berubah menjadi warna merah tua. Semakin lama waktu fermentasi warna kombucha semakin bening (Puspitasari et al, 2017). Hal ini disebabkan fermentasi yang semakin lama mengakibatkan jumlah mikroba kombucha semakin bertambah dan memperbesar kesempatan mikroba untuk mendegradasi senyawa-senyawa dalam kmbucha yang dapat merubah warna kombucha semakin terang (Naland, 2004).

\section{Uji pH Rebusan Rosela dan Kombucha Rosela}

Tabel 4 Hasil Uji pH Kombucha Rosela

\begin{tabular}{lrrrrrrrrrr}
\hline Perlakuan & Rebusan & \multicolumn{9}{c}{ Fermentasi Kombucha Rosela Hari Ke } \\
\cline { 3 - 10 } & Rosela & $\mathbf{1}$ & $\mathbf{3}$ & $\mathbf{5}$ & $\mathbf{7}$ & $\mathbf{9}$ & $\mathbf{1 1}$ & $\mathbf{1 3}$ & $\mathbf{1 5}$ \\
& & & & & & & & & \\
\hline R1 & 3,4 & 3,7 & 3,9 & 4 & 4 & 4,4 & 4,3 & 4,4 & 3,6 \\
R2 & 3,5 & 3,8 & 3,9 & 4 & 4 & 4,3 & 4,4 & 4,3 & 3,6 \\
R3 & 3,4 & 3,8 & 3,9 & 4 & 4 & 4,4 & 4,3 & 4,4 & 3,6 \\
Rata-rata & 3,43 & 3,76 & 3,9 & 4 & 4 & 4,36 & 4,33 & 4,36 & 3,6 \\
\hline
\end{tabular}

\begin{tabular}{lcr} 
Hasil & \multicolumn{1}{c}{ penelitian } & tingkat \\
keasamanan & kombucha & rosela \\
cenderung & mengalami peningkatan \\
selama fermentasi hari ke $1-13$ hal ini \\
disebabkan karena pertumbuhan bakteri \\
dan khamir pada fase lag (fase adaptasi)
\end{tabular} yang merupakan fase di mana mikroorganisme menyesuaikan dengan lingkungannya (Simanjuntak et al, 2016). Menurut penelitian Suhartatik et al. (2009) jumlah asam sebagai asam asetat dalam fermentasi kombucha rosella tidak terdapat kecenderungan tertentu. Kombucha rosella dengan kadar rosella $30 \mathrm{~g} / \mathrm{L}$, total asam mengalami penurunan setelah difermentasi selama 1 hari dan kemudian naik lagi. Namun pada kadar rosella $40 \mathrm{~g} / \mathrm{L}$, nilai total asam turun setelah hari ke-1 kemudian naik lagi sampai hari ke-5 dan turun lagi hingga hari ke-10. Keasaman kombucha cenderung naik turun. Hal ini disebabkan karena selain dihasilkan asam organik oleh bakteri asam asetat dan bakteri asam laktat, juga terjadi penggunaan asam organik oleh yeast sebagai sumber karbon.

Penurunan $\mathrm{pH}$ pada fermentasi hari ke 15 dapat disebabkan karena khamir mensintesis gula menjadi etanol yang kemudian dirombak oleh bakteri menjadi asam-asam organik, seperti asam asetat dan asam glukonat. Beberapa jenis asam-asam organik tersebut mengakibatkan penurunan $\mathrm{pH}$ pada kombucha. Pertumbuhan bakteri dan khamir pada fase logaritmik (fase eksponensial) yang merupakan fase di mana mikroorganisme tumbuh dan membelah pada kecepatan maksimum sehingga jumlahnya mikroorganisme meningkat dan $\mathrm{pH}$ menurun (Wrasiati et al, 2013). 


\section{Uji Total Asam Asetat Rebusan}

Rosela dan Kombucha Rosela

Uji total asam asetat dilakukan

untuk mengetahui tingkat keasaman pada rebusan rosela dan kombicha rosela.

Tabel 5 Hasil Uji Total Asam Asetat Rebusan Rosela dan Kombucha Rosela

\begin{tabular}{cccccccccc}
\hline Perlakuan & Rebusan & \multicolumn{7}{c}{ Fermentasi Kombucha Rosela Hari Ke } \\
\cline { 3 - 9 } & rosela & $\mathbf{1}$ & $\mathbf{3}$ & $\mathbf{5}$ & $\mathbf{7}$ & $\mathbf{9}$ & $\mathbf{1 1}$ & $\mathbf{1 3}$ & $\mathbf{1 5}$ \\
\hline \% Total & $2,33 \%$ & $2,68 \%$ & $2,74 \%$ & $2,96 \%$ & $2,96 \%$ & $3,27 \%$ & $3,32 \%$ & $3,48 \%$ & $3,59 \%$ \\
Asam & & & & & & & & & \\
\hline
\end{tabular}

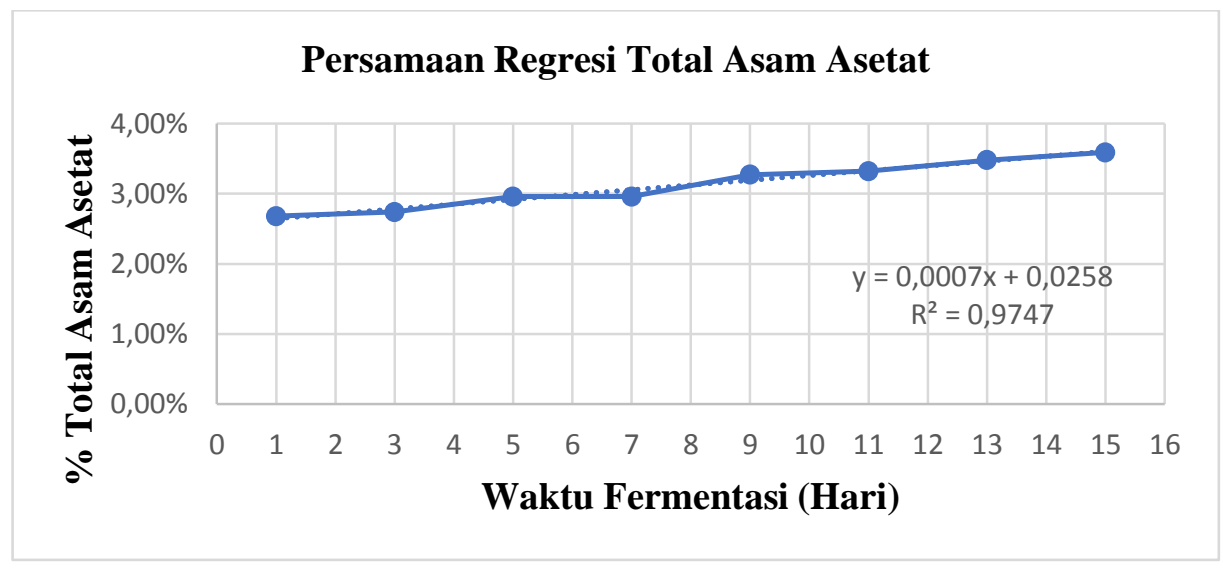

Hasil penelitian semakin lama waktu fermentasi, \% total asam asetat semakin meningkat. Peningkatan total asam asetat dikarenakan selama proses fermentasi khamir dan bakteri melakukan metabolisme terhadap sukrosa dan menghasilkan sejumlah asam-asam organik seperti asam asetat, asam glukonat dan asam glukoronat (Wistiana dan Zubaidah. 2015). Total asam asetat merupakan parameter penting dalam fermentasi kambucha sebagai metabolit yang dihasilkan mikroba selama fermentasi berlangsung (Goh et al, 2012). Hubungan antara waktu fermentasi dengan \% total asam dianalisa menggunakan uji regresi linier sederhana. Hasil persamaan regresi linier antar waktu fermentasi dengan $\mathrm{pH}$ didapatkan $\mathrm{y}=0,0007 \mathrm{x}+0,0258$ dengan $r=0,987$ yang berarti kriteria kekuatan hubungan adalah sangat kuat (0,9-1) menurut (Misbahuddin dan Hasan, 2014). Maka dari itu semakin lama waktu fermentasi, \% total asam asetat semakin meningkat. Peningkatan total asam asetat dikarenakan selama proses fermentasi khamir dan bakteri melakukan metabolisme terhadap sukrosa dan menghasilkan sejumlah asam-asam organik seperti asam asetat, asam glukonat dan asam glukoronat (Wistiana dan Zubaidah. 2015).

Hal ini sesuai dengan penelitian menurut Simanjuntak et al (2016) mengenai karakteristik kimia dan 
aktivitas antioksidan kombucha dari tumbuhan apu-apu (pistia stratiotes) selama fermentasi total asam yang dihasilkan semakin meningkat dikarenakan selama proses fermentasi khamir dan bakteri melakukan proses metabolisme terhadap sukrosa dan menghasilkan sejumlah asam-asam organik seperti asam asetat dan asam glukonat oleh karena itu terjadi peningkatan kadar asam-asam organik yang menyebabkan semakin tinggi total asamnya.

\section{Uji Aktivitas Antibakteri Escherichia coli}

Tabel 6 Hasil Uji Aktivitas Antibakteri Escherichia coli Rebusan Bunga Rosela dan Kombucha Rosela

\begin{tabular}{|c|c|c|c|c|c|c|c|c|c|}
\hline \multirow[t]{3}{*}{ Perlakuan } & \multicolumn{8}{|c|}{ Zona Hambat Escherichia coli (mm) } & \multirow[b]{3}{*}{15} \\
\hline & \multirow{2}{*}{$\begin{array}{c}\text { Rebus } \\
\text { an } \\
\text { rosela }\end{array}$} & \multicolumn{7}{|c|}{ Fermentasi Kombucha Rosela Hari Ke } & \\
\hline & & 1 & 3 & 5 & 7 & 9 & 11 & 13 & \\
\hline Kontrol (-) & 0 & 0 & 0 & 0 & 0 & 0 & 0 & 0 & 0 \\
\hline Kontrol (+) & 8,75 & 7 & 8 & 11 & 11 & 11 & 11 & 13 & 13 \\
\hline Replikasi 1 & 15,75 & 14 & 18 & 18 & 20,5 & 21 & 21 & 21,75 & 21,75 \\
\hline Replikas 2 & 15,25 & 13,2 & 15,25 & 18,25 & 21 & 21 & 21,25 & 21 & 21 \\
\hline Replikas 3 & 14,75 & 13 & 15,75 & 19 & 21 & 21 & 21 & 21,25 & 21,75 \\
\hline Rata-rata & 15,25 & 13,40 & 16,33 & 18,41 & 20,83 & 21 & 21,08 & 21,33 & 21,50 \\
\hline$\Sigma(\mathrm{SD})$ & 6,7212 & 5,9722 & 7,3963 & 8,0816 & 9,2574 & 9,3380 & 9,3801 & 9,3384 & 9,4190 \\
\hline
\end{tabular}

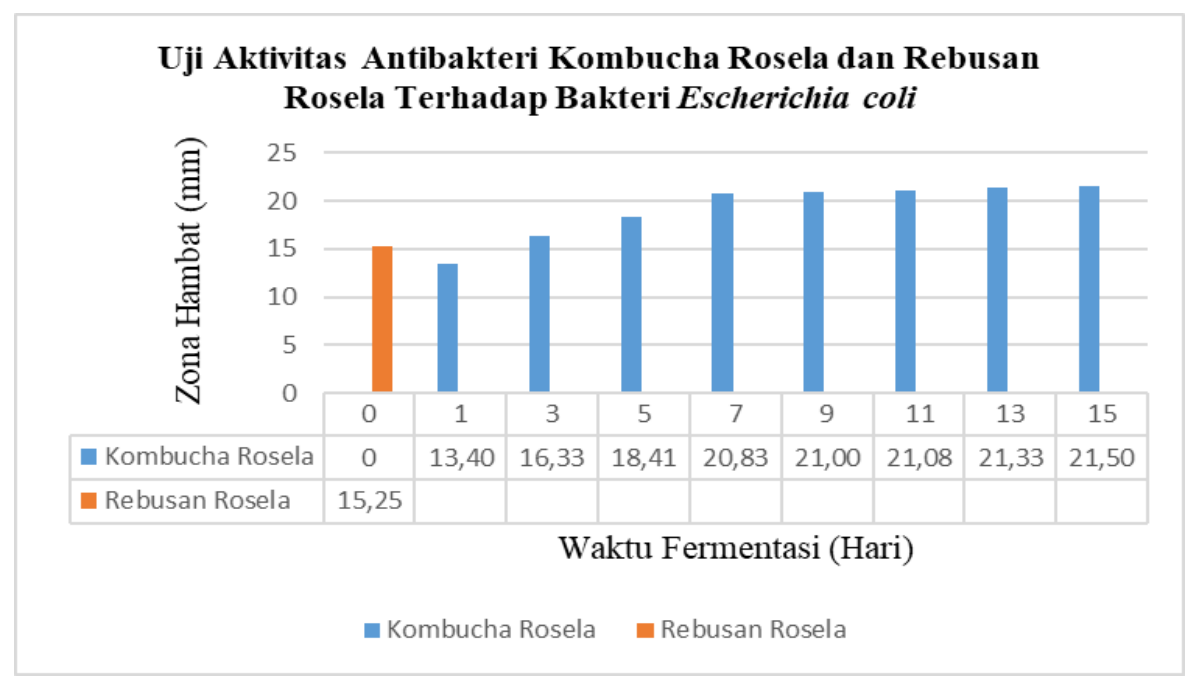

Zona bening atau zona hambat yang terbentuk akibat adanya aktivitas metabolit sekunder dan asam asetat yang terkandung dalam sampel yang diuji. Hasil zona hambat bakteri Escherichia coli pada rebusan bunga rosela yaitu 15,25 mm yang merupakan kategori daya hambat kuat, hal ini dapat disebabkan karena pada rebusan bunga rosela terdapat kandungan senyawa fenolik yang terdiri dari flavonoid, tannin, antosianin dan saponin (Estri dan Anggarbeni, 2015). Kombucha fermentasi hari ke 1 memiliki aktivitas 
antibakteri yang lemah dan kombucha rosela fermentasi hari ke 15 memiliki aktivitas antibakteri yang paling kuat, hal ini dikarenakan kombucha rosela memiliki senyawa asam asetat dan diduga dipengaruhi oleh senyawa flavonoid, saponin dan tanin yang masih terdapat pada kombucha. Asam asetat berperan sebagai antibakteri dengan cara mendenaturasi protein yang dapat menyebabkan aktivitas metabolisme sel bakteri berhenti (Simanjuntak dan Kurniawaty, 2019). Kandungan kimia saat fermentasi kombucha rosela masih tetap ada dan tidak dapat terurai akibat fermentasi. Fermentasi hanya menguraikan senyawa dari starter kombucha yang telah diberi, karena bakteri dan khamir pada kombucha tidak mampu untuk memecah senyawa kimia yang terkandung banyak pada bunga rosela (Fajriyah et al, 2015). Hasil ini sesuai dengan penelitian menurut Battikh et al. (2011) kombucha teh hitam dan teh hijau mempunyai aktivitas antibakteri dengan spektrum luas, karena mampu menghambat bakteri Gram positif maupun Gram negatif.

\section{Pengaruh Waktu Fermentasi Terhadap Aktivitas Bakteri Escherichia coli}

Tabel 7 Hasil Uji Pengaruh spearman

\begin{tabular}{lrr}
\hline \multirow{2}{*}{ Pengaruh } & \multicolumn{2}{c}{ Hasil } \\
\cline { 2 - 3 } & $\begin{array}{l}\text { Correlation } \\
\text { Coefficient }\end{array}$ & Sig. (2-tailed) \\
\hline Perlakuan & 0,927 & 0,000 \\
Aktivitas & 0,927 & 0,000 \\
\hline
\end{tabular}

Hasil uji pengaruh menggunakan uji spearman pada bakteri Escherichia coli menunjukkan nilai sig. (2-tailed) $<0,05$ dimana nilai sig yang menunjukkan terdapat korelasi yaitu sig. (2-tailed) $<0,05$, sehingga dapat disimpulkan data tersebut terdapat korelasi antara perlakuan dengan aktivitas. Hasil tingkat kekuatan hubungan diperoleh angka koefisien korelasi sebesar 0,927 dimana nilai koefisien korelasi yang menunjukkan angka 0,76-0,99 yaitu memiliki korelasi sangat kuat, sehingga dapat disimpulkan data tersebut terdapat korelasi sangat kuat antara perlakuan dengan aktivitas.
Semakin lama waktu fermentasi semakin berpengaruh terhadap aktivitas antibakteri hal ini disebabkan karena semakin lama waktu fermentasi kandungan asam asetat pada kombucha rosela semakin meningkat sehingga aktivitas antibakteri semakin kuat (Simanjuntak dan Kurniawaty, 2019) dan terdapat senyawa flavonoid, saponin dan tanin yang berperan sebagai antibakteri (Fajriyah et al, 2015). 
Analisis Perbedaan Aktivitas

Antibakteri Escherichia coli Rebusan

Bunga Rosela dan Kombucha Rosela

Terhadap Waktu Fermentasi

Uji lanjutan untuk melihat

perbedaan secara signifikan pada semua sampel dan masing-masing perlakuan, maka dari itu dilakukan analisa Uji Beda Kruskal Wallis dan Uji Beda Mann Whitney.

Tabel 8 Hasil Uji Beda Kruskal Wallis

\section{Kruskal Wallis}

\begin{tabular}{ll}
\hline Asymp. Sig. $\quad, 001$ \\
\hline
\end{tabular}

Hasil uji beda menggunakan uji Kruskal Wallis pada bakteri Escherichia coli menunjukkan nilai $\mathrm{p}<0,05$ dimana nilai sig yang menunjukkan terdapat perbedaan yaitu $\mathrm{p}<0,05$, sehingga dapat disimpulkan data tersebut terdapat adanya rata-rata dan perbedaan pada semua sampel. Rebusan bunga rosela dan kombucha rosela memiliki perbedaan aktivitas yang signifikan. Aktivitas antibakteri kombucha rosela lebih kuat dibandingkan dengan aktivitas antibakteri rebusan bunga rosela hal ini disebabkan oleh kandungan senyawa pada rebusan bunga rosela terdapat senyawa fenolik yang terdiri dari flavonoid, tannin, antosianin dan saponin yang dapat menghambat aktivitas antibakteri (Estri dan Anggarbeni, 2015), sedangkan kombucha rosela memiliki senyawa asam asetat dan senyawa flavonoid, saponin dan tanin yang dapat menghambat aktivitas antibakteri (Fajriyah et al, 2015). 
Tabel 9 Hasil Uji Perbedaan Mann Whitney

\begin{tabular}{|c|c|c|c|c|c|c|c|c|c|c|c|}
\hline & \multirow{2}{*}{ 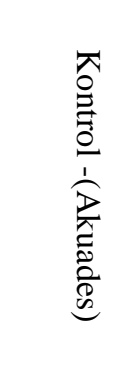 } & \multirow{2}{*}{ 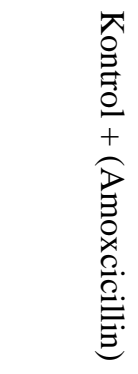 } & \multirow{2}{*}{$\begin{array}{c}\text { Rebusan } \\
\text { Rosela }\end{array}$} & \multicolumn{8}{|c|}{ Fermentasi Kombucha Rosela Hari Ke } \\
\hline & & & & 1 & 3 & 5 & 7 & 9 & 11 & 13 & 15 \\
\hline Rebusan Bunga Rosela & $0,037^{\mathrm{BS}}$ & $0,05^{\mathrm{BS}}$ & - & $0,05^{\mathrm{BS}}$ & $\begin{array}{c}0,261 \\
\text { BTS }\end{array}$ & $0,05^{\mathrm{BS}}$ & $\begin{array}{c}0,046 \\
\text { BS }\end{array}$ & $\begin{array}{c}0,037 \\
\text { BS }\end{array}$ & $\begin{array}{c}0,046 \\
\text { BS }\end{array}$ & $0,05^{\mathrm{BS}}$ & $0,046^{\mathrm{BS}}$ \\
\hline Kontrol - (Akuades) & - & $0,037^{\mathrm{BS}}$ & $0,037^{\mathrm{BS}}$ & $\begin{array}{c}0,037 \\
\text { BS }\end{array}$ & $\begin{array}{c}0,037 \\
\text { BS }\end{array}$ & $\begin{array}{c}0,037 \\
\text { BS }\end{array}$ & $\begin{array}{c}0,034 \\
\text { BS }\end{array}$ & $\begin{array}{c}0,037 \\
\text { BS }\end{array}$ & $\begin{array}{c}0,034 \\
\text { BS }\end{array}$ & $\begin{array}{c}0,037 \\
\text { BS }\end{array}$ & $0,034^{\mathrm{BS}}$ \\
\hline $\begin{array}{l}\text { Kontrol + } \\
\text { (Amoxcicillin) }\end{array}$ & $0,037^{\mathrm{BS}}$ & - & $0,05^{\mathrm{BS}}$ & 0,077 & $0,05^{\mathrm{BS}}$ & $0,05^{\mathrm{BS}}$ & $\begin{array}{c}0,046 \\
\text { BS }\end{array}$ & $\begin{array}{c}0,037 \\
\text { BS }\end{array}$ & $\begin{array}{c}0,034 \\
\text { BS }\end{array}$ & $0,05^{\mathrm{BS}}$ & $0,046^{\mathrm{BS}}$ \\
\hline
\end{tabular}

Keterangan: $\quad$ BS $=$ Beda Signifikan $\quad$ BTS $=$ Beda Tidak Signifik 
Hasil uji perbedaan aktivitas menggunakan uji Mann Whitney pada bakteri Escherichia coli menunjukkan nilai $\mathrm{p}<0,05$ dimana nilai sig yang menunjukkan terdapat korelasi yaitu $\mathrm{p}<0,05$. Dari hasil tersebut perbandingan aktivitas antibakteri rebusan bunga rosela dengan kontrol negatif (akuades) memiliki perbedaan signifikan, rebusan bunga rosela dengan kontrol kontrol + (amoxcicillin ), rebusan bunga rosela dengan kombucha rosela memiliki perbedaan signifikan pada fermentasi hari ke 1, 5, 7, 9,11, 13 dan 15, sedangkan pada fermentasi hari ke 3 beda tidak signifikan, hal ini disebabkan karena rebusan bunga rosela dan kombucha rosela fermentasi hari ke 3 memiliki aktivitas antibakteri yang sama dan kandungan senyawa yang terkandung juga sama karena pada kombucha rosela khamir dan bakteri belum melakukan metabolisme terhadap sukrosa dan belum menghasilkan sejumlah asamasam organik seperti asam asetat, asam glukonat dan asam glukoronat yang banyak (Wistiana dan Zubaidah. 2015).

\section{SIMPULAN}

Kesimpulan dari penelitian ini adalah :

1. Kombucha rosela mengandung senyawa asam asetat yang digunakan sebagai antibakteri. Hasil penelitian menunjukkan waktu fermentasi dengan aktivitas antibakteri Escherichia coli memiliki pengaruh yang signifikan. Semakin lama waktu fermentasi asam asetat yang dihasilkan semakin banyak sehingga aktivitas antibakteri semakin kuat. Zona hambat paling optimum menghambat bakteri Escherichia coli adalah fermentasi kombucha rosela 15 hari sebesar 21,5 mm yang dikategorikan dengan daya aktivitas antibakteri sangat kuat.

2. Rebusan bunga rosela dan kombucha rosela memiliki perbedaan yang signifikan terhadap bakteri Escherichia coli pada fermentasi kombucha hari ke $1, \quad 5, \quad 7, \quad 9,11, \quad 13,15$ dan fermentasi kombucha rosela hari ke 3 tidak ada perbedaan signifikan terhadap rebusan bunga rosela, hal ini disebabkan karena rebusan bunga rosela dan kombucha rosela fermentasi hari ke 3 memiliki aktivitas antibakteri yang sama dan kandungan senyawa yang terkandung juga sama karena pada kombucha rosela khamir dan bakteri belum melakukan metabolisme terhadap sukrosa dan belum menghasilkan sejumlah asam-asam organik seperti asam asetat, asam glukonat dan asam glukoronat yang banyak.

\section{UCAPAN TERIMAKASIH}

Pada kesempatan ini, peneliti ingin mengucapkan terima kasih kepada berbagai pihak yang telah membantu terwujudnya penelitian ini :

1. Ketua Sekolah Tinggi Ilmu Perbankan Indonesia 
2. Ketua Lembaga Penelitian dan Pengabdian Sekolah Tinggi Ilmu Kesehatan

\section{DAFTAR PUSTAKA}

Aridona P. M., Wartini, M. N., dan Arnata, W. I. 2015. Pengaruh Lama Fermentasi Alami Secara Aerob Cairan Pulpa Hasil Samping Fermentasi Biji Kakao Terhadap Karakteristik Cuka Fermentasi. Rekayasa Dan Manajemen Agroindustri, 3(3), 82-91.

Battikh,. H. Chaieb,. K., Bakhrouf A., And Ammar. 2012 Antibacterial And Antifungal Activities Of Black And Green Kombucha Teas. Journal Of Food Biochemistry 1-6, 1745-4514.

Borkani, R.A. D. Monir and R. Zahra,. 2016. Study of the Anti-Bacterial Effects of Green and Black Kombucha Teas and Their Synergetic Effect against Some Important Gram Positive Pathogens Transmitted by Foodstuff, International Journal of Advanced Biotechnology and Research, Vol. 7(3), pp.17411747.

Borrás-linares, I., Fernández-arroyo, S., Arráez-roman, D., dan Palmerossuárez, P. A. 2015. Characterization of phenolic compounds, anthocyanidin , antioxidant and antimicrobial activity of 25 varieties of Mexican Roselle ( Hibiscus sabdariffa). Industrial Crops dan Products, 69, 385-394.

Cappuccino, James G. And Natalie, Sherman. 2007. Manual Laboratorium Biologi. Jakarta: EGC

Deghrigue, M. J. Chriaa. H. Battikh. K. Abid. dan A. Bakhrouf. 2013. Antipoliferativ and Antimicrobia Activites of Kombucha Tea. African Journal of Microbiology Research, 7(27),3466-3470.

Elliza,. N. 2010. Pengaruh Pemberian Madu Terhadap Bakteri Escherichia Coli Dan Staphylococcus Aureus. Universitas Islam Negeri Syarif Hidayatullah. Jakarta

Escherich, T. 1885. Die Darmbakterien des Neugeborenen und Sauglings. Fortschr. Med. 3: 515-522; 547554.

Estri, R.MM. dan Anggarbeni S. R. 2015. Uji Daya Hambat Air Rebusan Bunga Rosella ( Hibiscus Sabdariffa L . ) Terhadap Pertumbuhan Bakteri Esherichia Coli. Jurnal Wiyata, 2(1), 9-13.

Fajriyah, N. D. Y., Wahyuni D. dan Murdiyah S. 2015. Pengaruh Kombucha Sari Buah Belimbing Wuluh (Averrhoa Bilimbi L.) Terhadap Pertumbuhan bakteri 
Escherichia coli. Bioedukasi, $\operatorname{XIII}(2), 32-36$.

Goh, W.N., Rosma A., Kaur, B., Fazilah, A., Karim A.A. dan Rajeev Bhat. 2012. Fermentation Of Black Tea Broth ( Kombucha ): I . Effects Of Sucrose Concentration And Fermentation Time On The Yield Of Microbial Cellulose. International Food Research Journal, 19(1), 109117.

Hamad, A. S. Jumintera, E. Puspawinigtyas. dan D. Hartanti. 2017. Aktivitas Antibakteri Infusa Kemangi (Ocimum Basilicum L.) Pada Tahu Dan Daging Ayam Segar. Inovasi Teknik Kimia 2(1), $1-8$.

Hanani. E. 2015. Anlisis Fitokimia. Jakarta: EGC.

Handarini, K. 2014. Potensi Ekstrak Bunga Rosella (Hibiscus sabdariffa L.) Sebagai Pewarna Dan Pengawet Alami Pada Jelly Jajanan Anak. Jurnal Teknik Industri Heuristic, 11(2), 32-42.

Heron, M. 2015. National Vital Statistics Reports, 64(10).

Higginbotham, K. L., Burris, K. P., Zivanovic, S., Davidson, P. M., dan Stewart, C. N. 2014. Antimicrobial Activity of Hibiscus sabdariffa Aqueous Extracts against Escherichia coli O157: H7 and Staphylococcus aureus in a Microbiological Medium and Milk of Various Fat Concentrations. Journal of Food Protection, 77(2), 262-268.

Isriqomah dan Fdlil, P. 2013. Sistem Pakar Untuk Mendiagnosa Penyakit Saluran Pencernaan Menggunakan Metode Dempster Shafer. Jurnal Sarjana Teknik Infoematika 1 (1), 32-41

Jayabalan, R., Malbaša, R. V., Lončar, E. S., Vitas, J. S., dan Sathishkumar, M. 2014. A Review On Kombucha TeaMicrobiology, Composition, Fermentation, Beneficial Effects, Toxicity, And Tea Fungus. Comprehensive Reviews In Food Science And Food Safety, 13(4), 538-550.

Jung, E. Y. Kim. dan N. Joo. 2013. Physicochemical Properties And Antimicrobial Activity Of Roselle (Hibiscus Sabdariffa L.). Journal Of The Science Of Food And Agriculture, 93(15), 3769-3776.

Karyantina, M. dan Sumarni. 2017. Kombucha Rosela (Hibiscus sabdariffa L) Sebagai Agensia Probiotik. Riset Fair.

Kemenkes. 2011. Lampiran Peraturan Menteri Kesehatan Nomor 2406/Menkes/Per/Xii/2011

Tentang Pedoman Umum Penggunaan Antibiotik. Jakarta: Menteri Kesehatan Republik Indonesia, (874). 
Kemenkes RI. 2018. Hasil Utama Riset Kesehatan Dasar Jawa Timur 2018. Jakarta: Badan Penelitian Dan Pengembangan Kesehatan, Kementrian Kesehatan Republik Indonesia, 1-82.

Kowalk. dan Jennifer P. 2011. Buku Ajar Patofisiologi. Jakarta: EGC.

Kurniawan F. B., dan I. T. Shali. 2017. Bakteriologi: Praktikum Teknologi Laboratorium Medik. Jakarta: EGC.

Kuswiyanto. 2016. Bakteriologi 2: Buku Ajar Analisis Kesehatan. Jakarta: EGC.

Leal, J. M., Suárez, L. V., Jayabalan, R., Oros, J. H., dan Escalante-Aburto, A. 2018. A review on health benefits of kombucha nutritional compounds and metabolites. CYTA - Journal of Food, 16(1), 390-399.

Loncar, E. S. M. S. Đuric. R. V. Malbasa. K. G. Kanuric dan Milanović, S. D. 2014. Kinetics Of Saccharose Fermentation By Kombucha.Chemical Industry danChemical Engineering Quarterly 20(3), 345-352.

Jawetz., Melnick., dan Adelberg, 2007. Mikrobiologi Kedokteran. Edisi 23. Jakarta:ECG.

Kumar, V and V.K. Joshi. 2016. Kombucha :Technology, Microbiology, Production, Composition and Therapeutic
Value, Intl. J. Food. Ferment. Technol. Vol. 6 (1), pp.13-24

Mardiah, Zakaria, F. R., Prangdimurti, E., Damanik, R. 2015. Perubahan Kandungan Kimia Sari Rosela Merah Dan Ungu (Hibiscus Sabdariffa L.) Hasil Pengeringan Menggunakancabinet Dryer Dan Fluidized Bed Dryer. Jurnal Teknologi Industri Pertanian, 25(1), 1-7.

May A. S. Narayanan. J. Alcock. A. Varsani. C. Maley dan A. Aktipis. 2019. Kombucha: a Novel Model System For Coorperation and Conflict in a Complex MultiSpecies Microbial Ecosystem. PeerJ, 1-22.

Misbahudin, Iqbal Hasan,. 2013. Analisis Data Penelitian Dengan Statistik, Jakarta, Bumi Aksara.

Mulyani, H. Widyastuti, S. H Dan V. I. E. 2016. Tumbuhan Herbal Sebagai Jamu Pengobatan Tradisional Terhadap Penyakit Dalam Serat Primbon Jampi Jawi Jilid I Hesti. Jurnal Penelitian Humaniora, 21(2), 73-91.

Naland, Henry. 2004. Kombucha: Teh Ajaib Pencegahan Aneka Penyakit. Jakarta: PT Agromedia Pustaka.

Naland, Henry. 2008. Kombucha Teh Dengan Seribu Khasiat. Jakarta: PT Agromedia Pustaka.

Ngatijo, Pranjono, Torwati, Waringin. 
W. M. 2017. Analisis Kadar Uranium dan Kasaman Untuk Menentukan Kebutuhan Soium Hidrksida Pada Penetralan Limbah Uranium Cair di Laboratorium Kimia Instalasi Elemen Bakar Eksperimental (19).

Nurnasari, E., dan Khuluq, A. D. (2018). Potensi Diversifikasi Rosela Herbal (Hibiscus sabdariffa L.) untuk Pangan dan Kesehatan. Buletin Tanaman Tembakau, Serat dan Minyak Industri, 9(2), 82 .

Pleczar dan Chan. 2008. Dasar-Dasar Mikrobiologi (Jilid 1). Jakarta: Universitas Indonesia Press.

Pratiwi T.Sylfia. 2008. Mikrobiologi Farmasi. Jakarta: Erlangga.

Puspitasari, Y., Palupi, R. dan Nurikasari, N. 2017. Analisis Kandungan Vitamin C Teh Kombucha Berdasarkan Lama Fermentasi Sebagai Alternatif Minuman Untuk Antioksidan. Global Health Science, 2(3), 245253.

Radji, M. 2010. Buku Ajar Mikrobiologi. Jakarta: EGC.

Rahardja, T. H. T. dan K. 2007. Obatobat Penting. Jakarta: PT. Elex Media Komputindo.

Ray B dan A Bhunia. 2018. Fundamental Of Microbiology
Fourthed. CRC Press. London, New York.

Riaz, G., dan Chopra, R. 2018. A review on phytochemistry and therapeutic uses of Hibiscus sabdariffa L. Biomedicine and Pharmacotherapy, 102, 575-586.

Riskesdas. 2018. Hasil Utama Riskesdas Penyakit Tidak Menular 2018. Kementrian Kesehatan Badan Penelitian dan Pengembangan Kesehatan , 8.

Shan, B. Y.Cai, J.D. Brooks and H. Cork., 2007.The In Vitro Antibacterial Activity of Dietary Spice and Medicinal Herb.

Sari, F., dan D. Aryantini, 2018. Karakter Spesifik Dan Pengaruh Pemberian Oral Ekstrak Terpurifikasi Kelopak Rosella ( Hibiscus Sabdariffa L .) Terhadap Makroskopis Organ Hepar Tikus Wistar Specific Character And Effect Oral Administration Of Rosella ( Hibiscus Sabdariffa L .) Calyx Puri. 1-9.

Simanjuntak. R. J. D. dan Kurniawaty E. 2019. Efek Ntibakteri Kopi Robusta yang Difermentasi dengan Kombucha Terhadap Salmonella typhi. J Agromedicine, 6(1), 83-88.

Simanjuntak, D. H., Herpandi., Lestari, D. S. 2016. Karakteristik Kimia dan Aktivitas Antioksidan Kombucha dari Tumbuhan Apu- 
apu (Pistia stratiotes) Selama

Fermentasi. Teknologi Hasil

Perikanan, 5(2), 123-133.

Simaremare, E. S. 2014. Skrining Fitokimia Ekstrak Etanol Daun Gatal (Laportea Decumana (Roxb.) Wedd) Eva. Pharmacy, 11(1), 98-107.

Suhartatik, N. M. Karyantina. dan I. T.Purwanti. 2009. Kombucha Rosella (Hibiscus sabdariffa Linn) dan Kemampuannya Sebagai Antihiperkolesterol. Agritech, 29(1), 29-35.

Sukandar, E. Y. R. Andrajati. J. I. Sigit. K. I. Adnyana, Setiadi, A. P. dan Kusnandar. $2008 . \quad$ Iso Farmakoterapi. Jakarta: PT. ISFI Penerbitan.

Sumampouw, O. J. 2018. Uji Sensitivitas Antibiotik Terhadap Bakteri Escherichia Coli Penyebab Diare Balita Di Kota Manado ( The Sensitivity Test of Antibiotics to Escherichia coli was Caused The Diarhhea on Underfive Children in Manado City ). 2(1), 104-110.

Suryani, Y. W. S. Listia. T. Cahyanto, I. kinasih. 2015. uji aktivitas antibakteri dan antioksidan infusum cacing tanah. Issn 19798911 (. IX(2).

Teerarak, M., Chamroon, L., Tangwatcharin, P., dan Pilasombut, K. 2017. Antioxidant and Antibacterial Activities against Food Pathogenic and Spoilage Bacteria by Hibicus Sabdariffa L . ( Roselle ) Extract. Journal of Agricultural Technology, 13(3), 379-391.

Trisia, A., Philyria, R., dan Toemon, A. N. 2018. Uji Aktivitas Antibakteri Ekstrak Etanol Daun Kalanduyung (Guazuma Ulmifolia Lam.) Terhadap Pertumbuhan Staphylococcus Aureus Dengan Metode Difusi Cakram (Kirby-Bauer). Anterior Jurnal, 17(2), 136-143.

Utomo, B. S., Fujiyanti, M., Lestari, P.W. dan Mulyani S. 2018. Uji Aktivitas Antibakteri Senyawa HexadecyltrimethylammoniumBromide Terhadap Bakteri Staphylococcus Aureus Dan Escherichia Coli (Antibacterial Activity Test of the C-4methoxyphenylcalix resorcinarene Compound Modified by Hexadecyltrimethylammonium). Jurnal Kimia Dan Pendidikan Kimia, 3(3), 201-209.

Villarreal-soto, S. A., Beaufort, S., Bouajila, J., Souchard, J., dan Taillandier, $\quad$ P. 2018 . Understanding Kombucha Tea Fermentation: A Review. Concise Reviews dan Hypotheses In Food Science 83(3).

Wistiana, D., \& Zubaidah, E. 2015. Berbagai Daun Tinggi Fenol 
Selama Fermentasi Chemical and Microbiological Characteristics of Kombucha from Various High Leaf Phenols During Fermentation. 3(4), 1446-1457.

Word Health Organization, 2002. Promoting Rational Use of Medicine. Geneva: Core Components

Wrasiati et al. 2013. Pemanfaatan Limbah Air Kelapa Menjadi Produk Coco Cider: Kajian Penambahan Gula Dan Waktu
Fermentasi. Jurnal Bumi Lestari, 13(1), 106-114.

Yanti, N. A., Ambardini, S., Ardiansyah., Marlina, W. O. L., Cahyanti, K,. 2020. Aktivitas Antibakteri Kombucha Daun Sirsak (Annona muricata L.) Dengan Konsentrasi Gula Berbeda. Berkala Sainstek, VIII (2): 35-40.

Zein, U. K. H. Sagala dan J. Ginting. 2004. Diare Akut Disebabkan Bakteri. e-USU Repository 1-15. 